\title{
Eco-Social Development Organization (ESDO), Their Program and Action
}

\author{
Afrin Jahan \\ MPhil Researcher, MSS (Social Welfare), University of Dhaka, Bangladesh
}

\begin{abstract}
I can affirm that field work assist a social worker to enhance his/her skill and experience and enhance practical knowledge. Every theory gets fulfillment by its successful application. Institute of Social Welfare and Research sends apprentice social worker to field work to apply theoretical knowledge of social work in real field. I was sent to sarkari shishu paribar for field work. I am very much delighted to work in this agency which is working for health, education, and economic development of population. Coming here for field work I have got chance to observe closely life style of different classes of people to listen tale of suffering. I have surprised observing practically that how these people is living struggling with poverty. This will enrich my experience and contribute to my future life. At the last moment, I wish ever-increasing prosperity, success, affluence and wealth of this organization. With the best wish of sarkari shishu paribar, I am closing the concluding report of field work. Finally, I would like to express my hearty \& devoted reverence to ray respective teacher \& Institute supervisor Md.Rabiul Islam and my Agency supervisor Md. Mizanur Rahman. For their cordial practice, I wish better guidance \& inspiration, which I have received from the beginning to end of my field work prospect of each sectors of Sarkari shishu paribar.
\end{abstract}

Keywords: Eco-Social Development

\section{Introduction}

Social work is the professional activity of helping individual, groups, or communities enhance or restore their capacity for social functioning and creating social condition favorable to that goal. The main objective of social work is to secure for each human living the economic necessities a decent standard of education, health and living conditions equal opportunities with his fellow citizen and the highest possible degree of self respect and freedom of thought and action without interfering with the same right of others.

As a profession social work is very much related with field and field work. Although the main goal of social work is to enhance the capacity of all kinds of individual, group and communities but it is more related with poor people. And field work is an important process to earn sufficient knowledge about all class of people.

\section{Field Work in Social Work Education}

Social work is a helping profession. It helps the people by the giving them access to the resources they need to improve and build brighter futures. Social workers try to help people make the most of their surroundings, their relationships, and their struggles with money or family.

Social work knowledge consists of two sides of two sides such as theoretical knowledge and practical training. Practical training is called field practice. It is considered to be an integrated part of social work education. In this process, we get opportunity to apply theoretical knowledge and techniques of social work in the society to meet the social problems.

\section{Concept of Field Work}

Field work is known to different persons in different name. In social work education the term "field work" is often used as practicum, field instruction, field education, field practicum and internship. Generally field work is a practical knowledge of any discipline. In case of social work, field work is the field training of new social worker. In developed countries it is known as "Field Work Practicum". It is nothing but learning by doing something practically.

According to International Encyclopedia of Social Science:

Field work comes to mean learning as for as possible to speak, think see, feel and act as a member of its culture and at the scientist from a different culture.

According to S. Clenent Brown and E.R. Gloyne:

Any kind of practical experience in a Social Organization or agency if this experience has been deliberately arranged for the education of student who are under taking course party or wholly those who intend to become social workers.

A.M.A. Momen in Field Work Manual has said:

Field work program is designed to help and guide a student to develop his skill and competence for his independent professional functioning and carrying our appropriate responsibilities.

So, field work is a mechanism that gives a social worker clear idea about different kind of social problem and its unraveling, which influence individuals groups and communities in their social role. It is also helpful for social worker to know about social policy, rules and regulations and activities of different welfare agencies.

\section{Aims and Objectives of Field Work}

Field work is a way to apply earning knowledge efficiently. It has made social work as an opportune profession. Important objectives of field works are; 


\section{International Journal of Science and Research (IJSR) \\ ISSN (Online): 2319-7064 \\ Index Copernicus Value (2013): 6.14 | Impact Factor (2015): 6.391}

- To help social work students to work efficiently in practical life

- Helping to apply social work knowledge

- To help to know administrative structure of Welfare sector agencies

- To help to achieve self dependency in working field

- To help to manifestation professional right

According to "The view committee on social work education in India" the objectives of social field work are:

- Development of skill in problem solving at the mean and micro levels

- Integration of class room learning with field practice

- Development of skills required for professional practice at the particular level of learning

- Development of professional attitudes values and commitment

- Development of self-awareness and professional ideal

So we can say that the main objective field work is to help social worker to apply social work knowledge in professional and practical life.

\section{Historical Background of Field Work}

In nineteenth century, when social work turn into a professional activity from that times field work had been included as a part of social work profession. Field work starts as institutional activities from England and America as like as social work. Some COS officer had been avid for field work training to unravel the multilateral problem created from the economic recession in 1873. In 1893, Anna L. Dhawes in an international conference by name "International Congress of Charities; Correction and Philanthropy" presented a proposal to include field work in social work education at Chicago in America. As a result of this proposal Mary Richmond established "Training School for Applied Philanthropy" in 1897.

With the cooperation of "Ges Charity Organization Society" the institution started a training workshop with 30 students in 1897. Only after three years the institute had started a training course with duration of 8 month. Later it has been transferred into "New York School of Social Work". In 1940 it has been included with "Colombia International University". After 1940 it has spread in different countries all over the world include Canada and UK. In 1950 United Nation declared social work as a profession. Actually the history of and history of field work is related with each other.

In the early 1900 's, the social work movement in America created many programs and services that we largely take for granted today. Social workers addressed the basic needs of the poor and immigrants, by promoting safety and sanitation initiatives. The early American social workers were also advocates for issues that continue to be goals of the profession today, such as increasing access to suitable housing and medical care, obtaining fair wages, and providing health and life-skills education to the community.
Dr. Richard Cabot, a senior physician at MGH, hired the first social worker in 1905 to provide social work services in the outpatient clinics. In 1906, Dr. Cabot met Ida Maude Cannon and hired her to jointly organize the nation's first hospital-based social work program. Of Cabot, Ida commented, "He was presenting the idea of social service within the hospital where sick patients, although separated from their home and families, nevertheless cannot separate themselves from their personal problems." At the time, Ida Cannon was enrolled in the newly established Boston School for Social Work (now Simmons College). Upon her graduation in 1907, Cannon joined Cabot's staff as a permanent member.

In 1914 Ms. Cannon was named Chief of the MGH Social Service Department, the first organized social work department in a hospital. This was a significant appointment as only three Chiefs functioned in the hospital at that time, Chief of Medicine, Chief of Surgery, and, then, Chief of Social Work.

The social work program was further developed under her tenure and became a department at MGH in 1919. At its inception and for the first ten years, social workers provided care in the out-patient clinics. The focus was not only on the patients' medical care but also broadened to include community and environmental awareness as it impacts patient care. MGH social work services began by helping patients afflicted with neurological ailments, venereal disease, and tuberculosis.

Ms. Cannon also assisted in founding the American Association of Hospital Social Workers in 1918 and was the recipient of the Massachusetts Public Health Association's Award for Distinguished Service. Since 1971, the Ida M. Cannon Award has been presented annually to an administrator of a social work department in a health care setting who has demonstrated outstanding leadership. This is the highest award given by the Society for Social Work Leadership of the American Hospital Association. Many of Ms. Cannon's early principles of sound social work practice, especially her strong patient advocacy, continue to represent core values for practitioners of her profession in the dawn of the 21 st century!

Ms. Cannon retired in 1945, and Josephine Barbor succeeded Ms. Cannon as Chief. By 1945, the department was fully integrated into the hospital and included 31 social workers. Ms. Barbor was a proponent of education and research into the social needs of patients and families. She also was a strong advocate for her staff. She recognized the emotional strains for patients, families, and staff, incurred by constant exposure to devastating illnesses. She had been a social worker on the front lines of World War I and saw the devastating effects that illness and trauma had on one's emotional health. One of Ms. Barbor's innovations was the creation of safe, private waiting rooms and meeting places within the hospital.

Eleanor Clark, who had also been an MGH social worker, succeeded Ms. Barbor in 1964. Ms. Clark's expertise was in outpatient psychiatric social work, and she led the department during an era of sweeping social reform. During 


\section{International Journal of Science and Research (IJSR) \\ ISSN (Online): 2319-7064 \\ Index Copernicus Value (2013): 6.14 | Impact Factor (2015): 6.391}

Ms. Clark's tenure, Medicare and Medicaid funding for the first time provided universal access to health care for the nation's elderly Noted for innovation, Clark developed the Transfer Office and the Adult Foster Family Care Program. The Transfer Office assured continuity of care for patients from the hospital to the community, through a team of social workers and continuing care nurses. The Adult Foster Family Care Program provided foster care as an alternative to nursing homes for elderly patients, and was later expanded to include persons with disabilities and HIV. This program is an active part of the Social Services Department today. Together with an MGH trustee, (Mrs. Jane Mortimer Clafflin) Ms. Clark was also instrumental in the creation of the Chelsea Health Center, which continues to be an integral part of that community.

In early 1984, Eleanor Clark was promoted to Associate General Director of $\mathrm{MGH}$, the first woman to hold this position. She was given responsibility for designing and implementing hospital-wide programs for the elderly. Sadly, she died later that year. Named in her honor were Clark House Nursing Home and the public square adjacent to the former Chelsea Health Center, which she had co-founded. An award for innovative program development was also created in Ms. Clark's honor and was instituted by the national Society for Social Work Leadership in Health Care.

Evelyn Bonander followed Ms. Clark as Chief in 1985. Continuing in the tradition of her predecessors, Ms. Bonander focused on strengthening clinical competence, creating socially relevant programs, and combining research and practice. Under her leadership, social work creatively and effectively responded to the increased pressures due to "managed care," including managed health care initiatives, health care budget crises and subsequent changes in health care reimbursement, and increasing patient care needs. She collaborated in the creation of a nurse case management role to assume accountability for medical discharge planning. The differentiation between case management and social work allowed social workers to assume greater clinical responsibility in patient care. Social work practice now focuses on helping patients and their families with their psychosocial problems, emotional responses to illness, and connecting them to supportive community programs

\section{Historical Background of Field Work in Bangladesh}

Practical social work started in Bangladesh at Pakistan period. 1953 a specialist group of United Nation started a training course on social work in Dhaka. According to the suggestion of specialist group a tentative Urban Community Development started in 1954 in Dhaka. In 1955 in the Dhaka Medical College Hospital, hospital social service has been started as a helping service sector. In 1958-59 seasons established "Institute of Social Welfare and Research" under the University of Dhaka.

Shed under the University of Rajshahi. Later Shahjalal International University has started social work as Honors' subject. Now a day's Social welfare is important Honors subject of National University and an important optional subject in intermediate level.
In Bangladesh theoretical and field work practice of social work is continuing equally. Theoretical and practical social work is equally important for our country.

\section{Importance and necessity of Field Work}

Field work is nothing but learning by doing something practically. So field work is an essential part of social work. Theoretical knowledge is meaningless without practice. Theoretical knowledge is fretful when it is in practice.

According to the United Nations: It is important that students should be helped to develop the attitude of mind leads them to make connections between study and relief. It is needed vital that this should be done if students are to become processional practitioners in the field rather than good natured amateurs of technicians applying narrow skills by rule of thumbs methods.

The important sides of field work are:

- To earn experience by applying different methods of social work

- To able a new social worker adopting with working environment

- To develop professional concept of students

- Increasing self-dependency

- To create positive attitude towards social problem

- To adjust scientific theory with practice

- So, we can say that, field work is a practical side of theoretical discipline.

\section{Historical background and introduction of the agency}

In 1944, Bengal orphan and widow act was passed for the man agreement of orphanages. At the government level, primary education directorate was initially responsible to run the state orphanages. Since the inception of the department of social services in 1961, the responsibilities of running the state orphanages had been transferred of the DSS. There are 85 Sarkari shishu paribar under the Depart men of social service all over the country with a capacity of 10375 orphan's .among which 44 institution are earmarked for boys, 40 of girl and I for both sexes. Sarkari shishu paribar of Mirpur was established in 1986 under the department of social service .it is for the boys. It is located at Mirpur, block $-\mathrm{B}$, road no- 1 Dhaka -1216.

\section{Goals and Objectives of Sarkari shishu paribar}

To obtain the goal the main objectives sarkari shishu paribar are:

- To take care of orphan children and destitute children

- To provide love and affection and to the orphans and destitute children.

- To provide vocational for e employment

- To provide employment opportunities

- To achieve sustainable improvements of lives and improve access to socio-economic opportunities for the orphan and poor through increase health, behavior change advocacy and awareness rising of the community people. 


\section{International Journal of Science and Research (IJSR) \\ ISSN (Online): 2319-7064 \\ Index Copernicus Value (2013): 6.14 | Impact Factor (2015): 6.391}

- To improve the oral health of the people of Bangladesh through oral health promotion and provision of basic oral health care, especially for the children

- To reduce the malnutrition, prevalence of underweight, prevalence of night blindness, prevalence of anemia, and prevalence of Iodine Deficiency.

- To increase house food consumption.

- To provide arsenic-safe water, medical support, who in fact, had been in taking arsenic contaminated drinking water and to strengthen the capacity of community people to cope with arsenic poisoning?

- Ensure adequate sanitation and safe water supply in unserved and underserved areas particularly for the poorest and improve standards of hygienic practice and behavior on a sustainable basic. To assist foreign visitors in learning and understanding Bengal language and culture. Eventually our endeavor is to help the country by improving the effectiveness of our foreign about our culture context as they work with the local people.

- To increase the quality of sports establishing peace, justice and friendship in the country and beyond.

- To bring awareness of adolescent boys.

- Enhance leadership and management capacity for the better benefit of the community people.

- Providing quality education and some extra- curricular support to poor children in that institute.

- To increase land water productivity for improvement food security and livelihood in coastal zones in a manner that is environmentally sustainable and socially acceptable to various users.

- To empower socially marginalized and economically poor communities, so that they are able to work and act collectively.

\section{Functions of Sarkari shishu paribar}

Sarkari shishu paribar has different types of program tor the welfare of residents of family who o are orphan and destitute children the function which are existing are described in following.

\section{General education program}

Under the general education program of Sarkar shishu paribar provides general education from baby to H.s.c. sarkari shishu paribar teaches the students are studying in class baby to two. Then they ate admitted are other mainstream school. They are provides khata, pen pencil and other educational material free of cost. The students who secure good result. They are given opportunities' higher education.

\section{Religion and technical education}

Sarkari shishu paribar provides religion and technical education to the resident of the agency. There is a teacher for teaching Arabic. There are an also mosque for praying in there. There are Arabic book and kitab. They read the Arabic language and pay namaj.

\section{Vocational and technical training}

Sarkari shishu paribar provides vocation al or technical training to the children of the agency for self motivated of making skilled man power. The children who are not able to make good academin results they are admitted in technical school. They are also provided computer training in the agency.

\section{Sports, cultural and entertainment program}

Sarkari shishu paribar arranges physical exercise in the morning at the yard of the agency regularly. It also arranges different sports, cultural program, in different times for different occasion like $16^{\text {th }}$ December, 26march, 21th February. They are also provides different sports institution.

\section{Health and medical program}

There is a part time doctor in the Sarkari shishu paribar who provides treatment to the children. They are also a compounder who supervised the overall children. They give medicine in the free of cost. Moreover, compouner all time gives advice to the children about health and nutrition and about the need of nutrition food

\section{Admission of the children}

The children who are orphan and destitute they are admitted in the Sarkari shishu paribar under some rules and regulations of the agency. The guardian of the orphan and destitute children apply for admission of their children on a specific form which is provided by social services department. The application is scrutinized by an admission committee. Scruitinizing the application the children are admitted. Photograph, date of birth, family history, and health information etc of children are presented in a life and one after another month whole activities are evaluated. These activities are supervised by institute sub-supervisor.

\section{Maintain of the children}

Government provides 1500 taka in per month for each resident to the agency for maintaining. 1150taka is given for food and 150taka is given for other expenditure.

\section{Rehabilitation program}

Sarkari shishu paribar rehabiliates the children who are above 18 years old through providing sewing machine, technical educator like computer education, employment , and socially. This agency has rehabilitate 108 residents from 1972; they are rehabilitated through following ways:

- Through the employment -30 residents

- Through educaton-24 residents

- Through training -22 residents

- Through other -32 residents

- Total number of the children is 108 .

\section{Provision of daily necessities}

Daily necessities like soap, coconut oil, shoe, bed shed and other dresses are provided to the children.

\section{Management activities}

A sub supervisor supervised the whole management activities. Total16 officials work under the supervisor of the sub supervisor. They supervise daily studying, having technical education, sports and recreation etc.

\section{Financial activities}

Sarkari shishu paribar is an institute of a social service department under ministry of social welfare. This institute gets financial fund from social service department and whole 


\section{International Journal of Science and Research (IJSR) \\ ISSN (Online): 2319-7064}

Index Copernicus Value (2013): 6.14 | Impact Factor (2015): 6.391

expenditure are met according to some rules and regulation for this fund.

\section{Organ of the agency}

There are three organs of the sarkari shishu paribar. The organs of the agency are following:

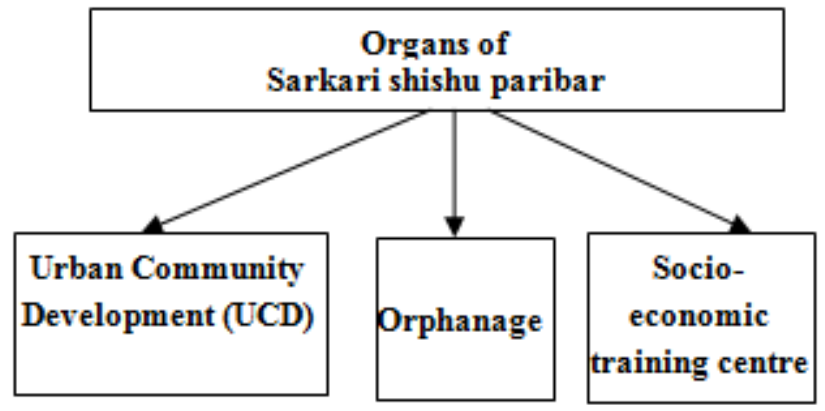

Target group of the agency

The target group of the agency mainly is the poor orphan and destitute children.

\section{Limitation of the agency}

Sarkari shishu paribar has some limitation the limitation are described in following ways :

- The orphan of ate agency do not gets nutritious food to eat. For this reason they suffer from malnutrition.

- The orphan of the agency are ineffective in studying they do not get proper guideline. Because there is no proper education atmosphere and there is no special teacher for them

- Orphanage have to leave the agency at 18 years old .but all the orphanage are not rehabilitated because of the agency limitation

- Opportunities of technical education within agency are limited. There is no specific room and computer for providing technical education

- There is no sufficient table for studding, furniture for the children.

- There is no any library for the children in the agency

- The residents do not get daily necessities like soup, book, pencil khata coconut oil and necessities in sufficiency.

- The toilet and bathroom are not clean and neat and clean.

- There is no skilled and experience teacher to teach the children in the agency.

- Total 1500 taka is expenditure in per head but this amount taka is not sufficient.

My field work begins on 19 September 2007 through inauguration of field work orientation class. Where our expert teachers and agency officials of different recognized agency gives us instruction and recommendation about field work. After completing of 4 days orientation class on 23 September 2007 we went to Sarkari Shishu paribar at Mirpur to perform field work. In there, at first I met with assistant officer of this agency. Then I also met with agency subsupervisor Mr. Mizanur Rahman. Agency assigned some duties on me. With assigned duties I went to the child abounding place at the agency. In there I met with all of the staffs those are involved in the agency activities. Subsupervisor Md. Mizanur Rahman also assigned some special duty on me developing my social work skills.

\section{Assigned Duties on Me}

The aim of social work is to apply the skill, method, knowledge of social work practically. As a student of social work and apprentice social worker ,I went to Sarkari shishu paribar ads part of field work .i tried my best to perform my assigned duties and responsibilities properly. The assign duties and responsibilities on me are mentioned in following:-

- To teach the resident of the agency

- To supervise neat and cleanliness of the children

- To know the problem of the residents

- To know about the administrative process of the agency

- To take special care on weak student

- To apply theoretical knowledge of social work in practically in field level

- To build up rapport with agency sub-supervisor and other officials of the agency.

- Helping the participants of this program by applying social work methods and knowledge

- Enthusing communities about education of their children

- Helping to develop their teaching skills

\section{Performance and Responsibility}

Obtaining effective knowledge I was devoted to my duty, I was dedicated to perform all assigned activities. I was keened and sincere in all cases. At the time of the report writing I am feeling that it will be very helpful for my professional life. The activities performed by me are as following:

- I aware with the different functions, staff, officials and others related with office and department of Sarkari shishu paribar.

- Case study is an important factor of social work, I awarded at first time with case study practically in the field work it was very challenging as well as interesting. And I have tried with intimacy to invent real picture.

- I would be present at the office regularly and signed on the attendance sheet and accomplishing daily work for certain hour left the office.

- Accomplishing long term case study was my regular duty

- Meeting with agency sub-supervisor and institute supervisor was my regular duty

- I have kept process recording daily and presented to supervisor in fixed date

- I would visit the whole place, piratical the discussion system talking with them

- I have made a report on performed activities and submitted to institute and agency sub- supervisor

- I also tried to aware him about some social issue from my own benevolence about following issue:

- About major social problem of Bangladesh like education, unemployment and others

- I have taught the students regularly and supervise their neat and cleanliness.

- I have taken special care on weak students

- I have build rapport with institute of sub-supervisor, resident and other officials of sarkari shishu paribar 


\section{International Journal of Science and Research (IJSR) \\ ISSN (Online): 2319-7064}

Index Copernicus Value (2013): 6.14 | Impact Factor (2015): 6.391

- I have created eagerness among the children to school regularly

- I have convinced them about the necessities of education,

- About total socio-economic situation of Bangladesh

I am very much pleased to work in this agency which is working for health education and economic development of children. Some weakness also found in my daily work. But with the proper guidelines officials of sarkari shishu paribar. I have tried to overcome my weakness. I wish increasing prosperity and fame.

\section{Acquired Experience}

Field work needed to apply theoretical knowledge in real aspect. I have acquired various types of experience in this institute which will be resource in my life. Success and failure are inextricably involved with life; failure is the pathfinder of success. I confess that there are some failures and inadequacy in my work as hundred percent success is about impossible. I have wanted to learn how to work as an apprentice social worker and to build up myself as a professional social worker. Field work requires an appropriate institute where a practitioner can be able to apply his theoretical knowledge fully; Sarkari shishu paribar of Bangladesh is such an institute where I have been able to enrich acquired experience through availing my theoretical knowledge:

- Clear idea about Sarkari shishu paribar activities in Bangladesh

- Practical effectiveness of Sarkari shishu paribar activities in Bangladesh

- I have gained experience about orphaned and destitute children

- Illiteracy is a great problem in education sector of Bangladesh

- Adolescent awareness is an important factor for developing nation

- I had chance to observe lifestyle of different classes of people and their attitude.

I have got pragmatic experience to work with poor helpless people poor people struggling life helplessness of orphan adults touched me. These parts of population can be turned into resource; I have grown ambition to work for their development.

\section{Acquired experience through imposed responsibilities}

I have wanted to learn how to work as an apprentice social worker to build up as a professional social worker. I have got chance to build up myself appropriately as social worker applying theoretical knowledge in real aspect some speech about my success in field work as following:

\section{Limitation in accomplishing imposed responsibilities}

Complete success requires time, patience and proper environment. In many times all responsibilities cannot be performed properly due to scarcity.

I had some drawbacks beside success during work in Heed Bangladesh. These are following:
During taking case history, data collection has been interrupted due to lack of confidentiality and proper environment. Wit hood it case has hilled inform dim.

Some case have provide excessive in for motion for help. That is why real information has been overlapped.

The cases that I have taken could not observe for long term due to lack adequate time.

I had to steer clear of many issue due to rules-regulates of agency.

\section{Application of social work knowledge, skill and experience}

A method is a conscious procedure, a designed means achieving a goal. In its outer aspect, a method is a way of doing something always discovers an integrated arrangement of knowledge, understanding and principles. Methods ate techniques sufficiently generalization to be common to a discipline, practice or range of discipline and practice. The term social workers used by especially those in education, to identify specific types of intervention. Social work activities that have been identified as methods include social case work, social group work, community organization, administration in social work, research policy, planning direct clinical practice, family and marital treatment, other micro practice and what is called generic social work practice combined micro-macro.

Generally social work methods are two types:
a) Basic Method
b) Auxiliary Method

Basic Methods:

There are three kinds of social basic methods

Social Case Work

Social Group Work

Community Organization

Auxiliary Methods:

There are three kinds of social basic methods:

Social Work Administration

Social Work Research

Social Action

According to the Dictionary of Social Work there are seven types of social work methods

Social case work

Social group work

Community social work

Administration organization

Research

Policy

Planning

\section{Application of social work}

Social case work, which helps the individual client to affect better social relationships and social adjustment that makes it possible for him to lead a satisfying useful life. Social case work is the art of assisting the individual in developing and making use of his personal capacity to deal with problem which he faces in his social environment. Social case work 


\section{International Journal of Science and Research (IJSR) \\ ISSN (Online): 2319-7064}

Index Copernicus Value (2013): 6.14 | Impact Factor (2015): 6.391

is an art in which knowledge of the science of human relations and skill in relationship are used to mobilize capacities in the individual and resources in the community appropriate for better adjustment between the client and all or any part of his total environment.

In case study it was my main method.

\section{Application of group work}

Social group is a method through which individual in groups are helped by a worker who guides their interaction in program activities so that they may relate themselves to others and experience growth opportunities in accordance with their needs and capacities. Group work is a method of social work which helps the individuals to enhance their social functioning through purposeful group experience and to cope more effectively with their personal group or community problems. It is an orientation and method of social work intervention in which small numbers of people who share similar interest or common problems convince regularly and engage in activities designed to achieve certain objective.

In visiting school, mothers club, adolescent girls club it was my main method.

\section{Limitation of field work in Bangladesh}

Field work is mandatory for the students of social word at their graduation and post -graduation level but t6here are many problems and limitation to practice field work in Bangladesh. The most common limitation of field work practice in Bangladesh is mentioned in following:

There are many social welfare agency in Bangladesh .but those agency are not suitable place to practice field work. So lack of social work philosophy based field work agency is a great problem of field work in Bangladesh.

- There are huge lack of regular and effective communication and co-ordination between agency and educational institution.

- The field work agency has no interest to render training to the student and they do not take proper care the students.

- There is lack of social back ground based/agency supervisor.

- The apprentice social workers do not participate in field work spontaneously.

- They are not sincere about field work

- The clients of agency have no interest to support the field worker by giving information.

- Financial problems are a great problem to carry on field work practice in Bangladesh.

- Field work report is not published in regular base lack of fund and sincerity.

\section{Recommendation}

Sarkari shishu paribar is servicing silently, but it has some obstacle parts. If it can be removed, its service will be better. So, some recommendations are given below.

- More skilled manpower should be involved to enrich the services.

- The number of bed ought to be increased.
- Much more advanced research programs should be accomplished for the improvement of the existing situation of education.

- The institute should take rehabilitation program strongly.

- The govt. should ensure modern machinery \& equipment.

- To manage uniform for students of pre- school. The system was provided previously. Due to insufficiency of money, the system has been closed, collecting donor this system should be prevailed again

- Due to insufficiency of fund, distrusting of food among students has been closed.

- Salaries and allowance of field workers should be increased.

- Due to inadequate fund man power bad communication system, many schools program should be expanded so that more poor and adolescent can be benefited.

\section{Conclusion}

In the last page of report, I can affirm that field work assist a social worker to enhance his skill and experience and enhance practical knowledge. Every theory gets fulfillment by its successful application. Institute of Social Welfare and Research sends apprentice social worker to field work to apply theoretical knowledge of social work in real field. I was sent to sarkari shishu paribar for field work. I am very much delighted to work in this agency which is working for health, education, and economic development of population. Coming here for field work I have got chance to observe closely life style of different classes of people to listen tale of suffering. I have surprised observing practically that how these people is living struggling with poverty. This will enrich my experience and contribute to my future life.

At the last moment, I wish ever-increasing prosperity, success, affluence and wealth of this organization. With the best wish of sarkari shishu paribar, I am closing the concluding report of field work.

Finally, I would like to express my hearty \& devoted reverence to ray respective teacher \& Institute supervisor Md.Rabiul Islam and my Agency supervisor Md. Mizanur Rahman. For their cordial practice, I wish better guidance \& inspiration, which I have received from the beginning to end of my field work prospect of each sectors of Sarkari shishu paribar.

\section{References}

[1] Annual Report ofsarkari shishu paribar 2010-2011

[2] Biestek, F.R. (1957). The Case Work Relationship, Loyal University Press, Chicgo.

[3] An International Encyclopedia of Social Science

[4] American psychiatric Association, (2005), Diagnostic \& StatjsticaL Manual of mental disorder ${ }^{1} .4^{\text {th }}$ edition, (DSM-4), Washington DC, USA.

[5] Barker, ReportL. (1995) "The Social work dictionary" NASW press, Washingtong DC.USA. Chowdhury,

[6] D. Paul (1971) Voluntary Social Welfare in India, sterling Publication, New Delhi.

[7] Choulshed, Vcronica (1991), Social Work Practice. An Introduction, $2^{\text {nd }}$ edition, Macmillan, London. 


\section{International Journal of Science and Research (IJSR) \\ ISSN (Online): 2319-7064}

Index Copernicus Value (2013): 6.14 | Impact Factor (2015): 6.391

[8] Encarta Dictionary 2009

[9] Hussain, N. and Alauddin, M. (1970). Introductoion to Social Work Methods, College of Social Welfare and Research Center

[10] Colernan James. C. Alnormal Phychology and Mopcrn life. $2^{\text {nd }}$ edition, Scott Forsman and Company, Chicago Atlanta Dallas Palo Alilanta Dallas Polo Alto Fair Lawn.

[11] Mumme, Norma, F (1979), "Socjal case work in Bangladesh". Bangladesh Books International Limited.

\section{Author Profile}

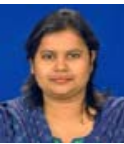

Afrin Jahan is MPhil Researcher, MSS (Social

Welfare), University of Dhaka, Bangladesh

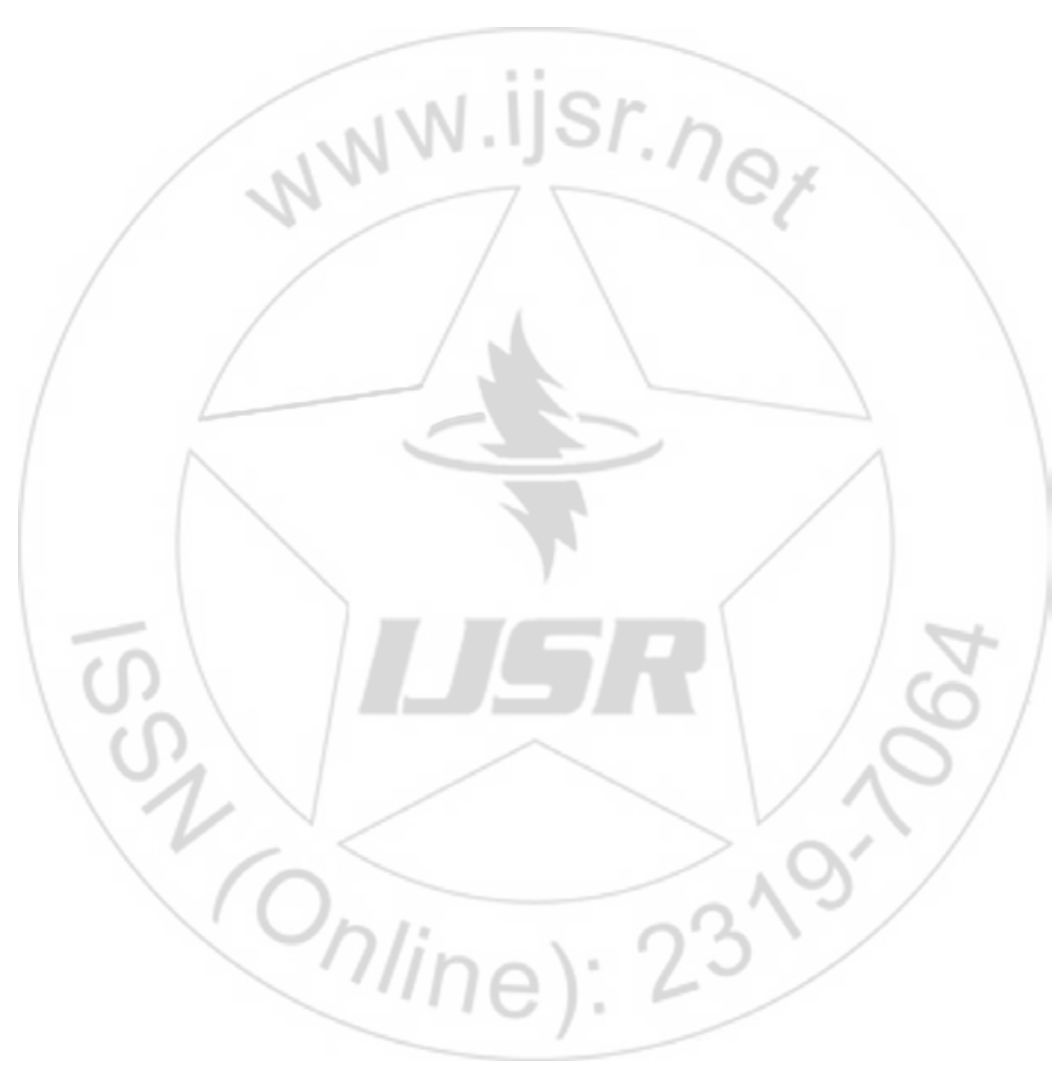

Volume 5 Issue 5, May 2016 